BUDGETING : Journal of Business, Management and Accounting

Volume 1, Nomor 1, Desember 2019

e-ISSN: 2715-2480

p-ISSN: 2715-1913

DOI : https://doi.org/10.31539/budgeting.vli1.779

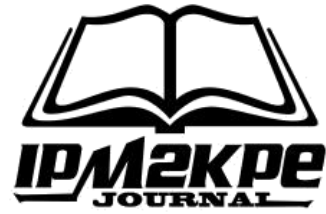

\title{
ANALISIS BEBAN KERJA DAN KONFLIK TERHADAP KEPUASAN KERJA KARYAWAN
}

\author{
Azis mauraksa ${ }^{1}$, R.Deni Muhammad Danial ${ }^{2}$, Nor Norisanti ${ }^{3}$ \\ Universitas Muhammadiyah Sukabumi ${ }^{1,2,3}$ \\ Aziz2019@gmail.com ${ }^{1}$
}

\begin{abstract}
ABSTRAK
Tujuan penelitian ini adalah untuk mengetahui pengaruh beban kerja karyawan dan konflik terhadap kepuasan kerja. Metode yang digunakan dalam penelitian ini menggunakan metode asosiatif. Teknik pengumpulan data yang dilakukan peneliti dalam penelitian yaitu melalui observasi, wawancara, angket, dokumentasi dan studi kepustakan. Teknik analisis data yang digunakan adalah teknik korelasi ganda, koefisien determinasi dan analisis regresi linier berganda. Berdasarkan perhitungan pengkategorian persentase skor data diketahui bahwa beban kerja berada dikriteria tinggi. Hal ini menunjukan adanya beban kerja pada Konveksi Neptuns Screen Printing Sukabumi. Berdasarkan perhitungan pengkategorian data yang didapatkan bahwa nilai konflik kriteria sedang. Hal ini diartikan bahwa konflik yang terjadi di dalam perusahaan Neptuns Screen Printing Studio masih bisa teratasi. Simpulan, terdapat pengaruh yang signifikan antara beban kerja dan konflik terhadap kepuasan kerja karyawan
\end{abstract}

Kata Kunci : Beban kerja, Konflik, Kepuasan Kerja

\section{ABSTRACT}

The purpose of this study was to determine the effect of employee workload and conflict on job satisfaction. The method used in this study uses an associative method. Data collection techniques used by researchers in research is through observation, interviews, questionnaires, documentation and library research. Data analysis techniques used are multiple correlation techniques, the coefficient of determination and multiple linear regression analysis. Based on the calculation of categorizing the percentage of data scores it is known that the workload is in high criteria. This shows the workload on Sukabumi's Neptuns Screen Printing Convection. Based on the calculation of categorizing data, it is found that the value of the conflict criteria is. This means that conflicts that occur within the company Neptuns Screen Printing Studio can still be resolved. Conclusion, there is a significant influence between workload and conflict on employee job satisfaction

Keywords: Workload, Conflict, Job Satisfaction 


\section{PENDAHULUAN}

Perusahaan Neptuns Screen Printing Studio merupakan suatu perusahaan dibidang usaha konveksi dan sablon yang beralamat usaha jalan Pelabuhan II km 3 No. 459 RT 004/RW 001 dengan jumlah 32 karyawan. Neptuns Screen Printing Studio dengan Akta No 9 tahun 2012 dengan Notaris Gunawan SH., MKn. Notaris di sukabumi. Penanggung jawab atau pimpinan usaha Neptuns Screen Printing atas nama Lutfi Mawardi yang diterangkan berdasarkan surat pengantar dari ketua RT atau RW bernomor 149/148/01/VII 2012.

Berdasarkan dari tabel Kepuasan kerja karyawan bulan Agustus - Desember menunjukan Karyawan yang mengeluh tentang Kepuasan kerja pada perusahaan Neptuns Screen Printing mengalami kenaikan yaitu sebesar Agustus 21,87\%, September $28,12 \%$, Desember $34,37 \%$. Permasalahan tersebut diduga disebabkan oleh kelebihan beban kerja karyawan. Perusahaan menuntut karyawan untuk dapat menaikan jumlah target produksi yang tidak sesuai dengan tugas awal yang diberikan perusahaan, sedangkan karyawan pada Konveksi dan Sablon Neptuns Screen Studio belum bisa mengoptimalkan harapan perusahaan. Penyebab lain yang diduga karena adanya konflik antar rekan kerja di perusahaan karena kesalahan komunikasi diduga antar karyawan memiliki konflik dalam bekerja. Hal ini yang menyebabkan tingkat kepuasan kerja karyawan semakin menurun.

Penelitian ini bertujuan untuk mengetahui beban kerja yang dialami pada konveksi dan sablon neptuns screen printing studio, mengetahui konflik yang terjadi pada konveksi dan sablon neptuns screen printing studio, mengetahui kepuasan kerja karyawan pada konveksi dan sablon neptuns screen printing studio, serta untuk mengetahui pengaruh beban kerja dan konflik terhadap kepuasan kerja karyawan konveksi dan sablon neptuns screen printing studio.

\section{KAJIAN TEORI}

Menurut Munandar (2001), beban kerja adalah keadaan dimana pekerja dihadapkan pada tugas yang harus diselesaikan pada waktu tertentu. Menurut Moekijat (2004), beban kerja adalah volume dari hasil kerja atau catatan tentang hasil pekerjaan yang dapat menunjukkan volume yang dihasilkan oleh sejumlah pegawai dalam suatu bagian tertentu. Dari definisi diatas dapat disimpulkan bahwa beban kerja adalah 
besaran pekerjaan yang harus dipikul oleh suatu jabatan atau unit organisasi. Adapun Menurut Soleman (2011), faktor-faktor yang memengaruhi beban kerja sebagai berikut:

1. Tugas (Task) adanya tanggung jawab yang harus dilaksanakan oleh setiap karyawan dengan tugas yang diberikan

2. Organisasi kerja sistem kerja yang diadakan perusahaan sesuai dengan ketentuan yang disepakati.

3. Lingkungan kerja adanya hubungan yang dijalin sesama rekan kerja selama bekerja di satu perusahaan yang sama.

Di dalam sebuah perusahaan, tidak hanya terdapat beban kerja melainkan sejalan dengan adanya konflik. Menurut Mangkunegara (2013) konflik adalah suatu pertentangan yang terjadi antara apa yang diharapkan oleh seseorang terhadap dirinya, orang lain, organisasi dengan kenyataan apa yang diharapkan. Untuk melihat dan mengukur terjadinya konflik, maka perlu diketahui dimensi konflik kerja, seperti menurut Fitriana (2013) dimensi konflik kerja adalah yaitu:

1. Kesalahan komunikasi. Apabila seseorang atau lebih menerima informasi yang berbeda atau tidak sama dengan sumber informasi sehingga terjadi perbedaan mendasar dalam mempersepsikan isi dari persepsi tersebut.

2. Perbedaan Tujuan. Apabila seseorang atau lebih memiliki ketidaksamaan dalam memandang tujuan-tujuan yang hendak dicapai sehingga terjadi pertentangan dalam menyikapi tujuan-tujuan tersebut.

3. Perbedaan dalam penilaian atau persepsi. Perbedaan dalam penilaian antara anggota dalam suatu organisasi, seringkali disertai oleh perbedaan-perbedaan dalam sikap, ketidaksesuaian nilai, persepsi, yang juga dapat menimbulkan konflik kerja.

4. Interpedensi aktivitas kerja. Terdapat adanya interpedensi kerja, apabila seseorang atau lebih saling tergantung satu sama lain dalam menyelesaikan tugas mereka masing-masing. Konflik akan terjadi apabila seseorang dari mereka diberi tugas secara berlebihan dan apabila salah seorang karyawan atau lebih harus menunggu atau menggantungkan pekerjaannya kepada karyawan lain.

5. Kesalahan dalam afeksi. Apabila sesseorang memperlakukan rekan kerjanya menjadi tidak nyaman dalam bekerja, terutama dalam hal perasaan atau suasana hatinya.

Hubungan antara beban kerja dan kepuasan kerja karyawan didukung dengan teori menurut Handoko (2000) menyimpulkan pada penelitian mereka bahwa kelebihan 
beban kerja berpengaruh secara signifikan negatif terhadap kepuasan kerja. Hubungan Konflik dengan Kepuasan kerja karyawan didukung dengan teori Hasibuan (2001). Konflik peran dapat menimbulkan situasi emosional individu misalnya terjadi ketegangan kerja, penurunan kepuasan kerja hingga berdampak pada organisasi dimana kualitas karyawan menurun dan tingkat keinginan berpindah kerja semakin meningkat.

\section{METODE PENELITIAN}

Metode penelitian yang digunakan dalam penelitian ini menggunakan metode deskriptif dan metode asosiatif. Teknik pengumpulan data menggunakan observasi, wawancara, angket, dokumentasi dan studi kepustakaan. Teknik analisis data menggunakan teknik korelasi ganda untuk menguji seberapa besar konflik dan stress kerja terhadap kepuasan kerja karyawan, Untuk mengetahui kontribusi pengaruh variabel $\mathrm{X}_{1}$ dan $\mathrm{X}_{2}$ terhadap $\mathrm{Y}$ menggunakan Koefisien Determinasi, Untuk memprediksi seberapa jauh perubahan nilai variabel dependen bila nilai variabel independen dirubah-rubah yaitu dengan menggunakan analisis regresi linier berganda, dan untuk menguji signifikansi koefisien korelasi ganda dan uji hipotesis digunakan rumus uji $\mathrm{F}$.

Adapun yang menjadi populasi dalam penelitian iniadalah karyawan konveksi dan sablon neptuns screen printing studio Sukabumi. Teknik pengambilan sampel yang digunakan peneliti adalah teknik sampling jenuh, dimana semua anggota populasi dijadikan sampel. Jumlah sampel dalam penelitian ini adalah 32 orang karyawan konveksi. Penelitian ini menggunakan uji validitas dengan umus korelasi product moment dan uji reliabilitas dengan rumus Cronbach's Alpha. Angket yang disebar menggunakan skala Likert.

\section{HASIL PENELITIAN}

Salah satu perusahaan yang bergerak di konveksi pakaian di Kota Sukabumi yaitu Neptuns Screen Printing Studio. Perusahaan ini adalah salah satu perusahaan yang bergerak sebagai penyedia jasa pembuatan pakaian jadi seperti kaos, kemeja, jaket, celana, rok dan topi. Pemilik dari perusahaan Neptuns Screen Printing Studio ini bernama Gyan Juniansyah dan Lutfi Mawardi, kedua pendiri perusahaan ini adalah saudara kandung yang merintis perusahaan ini sejak Juli 2012. Neptuns Screen Printing 
Studio bertempat di Jl. Pelabuhan II No. 312 Kota Sukabumi. Pada awalnya Neptuns Screen Printing Studio ini adalah konveksi kecil-kecilan yang target marketnya hanya toko-toko pakaian yang ada di Kota Sukabumi.

Berdasarkan perhitungan pengkategorian persentase skor data diketahui bahwa beban kerja sebesar 381 berada dikriteria tinggi. Hal ini menunjukan adanya beban kerja pada Konveksi Neptuns Screen Printing Sukabumi. Berdasarkan perhitungan pengkategorian data yang didapatkan bahwa nilai konflik sebesar 455 berada kriteria sedang. Hal ini diartikan bahwa konflik yang terjadi di dalam perusahaan Neptuns Screen Printing Studio masih bisa teratasi.

Berdasarkan perhitungan pengkategorian data yang didapatkan bahwa nilai kepuasaan kerja karyawan sebesar 290 berada kriteria sedang. Hal ini menunjukan bahwa kepuasaan kerja karyawan tergolong sedang, maka dapat diartikan kepuasaan kerja karyawan Konveksi Neptuns Screen Printing Studio sudah terlihat baik dan cukup puas dengan pemberian kepuasaan yang diberikan perusahaan.

\section{PEMBAHASAN}

Berdasarkan perhitungan pengkategorian persentase skor data diketahui bahwa beban kerja berada dikriteria tinggi. Hal ini menunjukan adanya beban kerja pada Konveksi Neptuns Screen Printing Sukabumi. Berdasarkan perhitungan pengkategorian data yang didapatkan bahwa nilai konflik kriteria sedang. Hal ini diartikan bahwa konflik yang terjadi di dalam perusahaan Neptuns Screen Printing Studio masih bisa teratasi. dalam sebuah perusahaan, tidak hanya terdapat beban kerja melainkan sejalan dengan adanya konflik. Menurut Mangkunegara (2013:155) Konflik adalah suatu pertentangan yang terjadi antara apa yang diharapkan oleh seseorang terhadap dirinya, orang lain, organisasi dengan kenyataan apa yang diharapkan. Untuk melihat dan mengukur terjadinya konflik, maka perlu diketahui dimensi konflik kerja, seperti menurut Fitriana (2013:192) dimensi konflik kerja adalah yaitu:

1. Kesalahan komunikasi. Apabila seseorang atau lebih menerima informasi yang berbeda atau tidak sama dengan sumber informasi sehingga terjadi perbedaan mendasar dalam mempersepsikan isi dari persepsi tersebut. 
2. Perbedaan Tujuan. Apabila seseorang atau lebih memiliki ketidaksamaan dalam memandang tujuan-tujuan yang hendak dicapai sehingga terjadi pertentangan dalam menyikapi tujuan-tujuan tersebut.

3. Perbedaan dalam penilaian atau persepsi. Perbedaan dalam penilaian antara anggota dalam suatu organisasi, seringkali disertai oleh perbedaan-perbedaan dalam sikap, ketidaksesuaian nilai, persepsi, yang juga dapat menimbulkan konflik kerja.

4. Interpedensi aktivitas kerja. Terdapat adanya interpedensi kerja, apabila seseorang atau lebih saling tergantung satu sama lain dalam menyelesaikan tugas mereka masing-masing. Konflik akan terjadi apabila seseorang dari mereka diberi tugas secara berlebihan dan apabila salah seorang karyawan atau lebih harus menunggu atau menggantungkan pekerjaannya kepada karyawan lain.

5. Kesalahan dalam afeksi. Apabila sesseorang memperlakukan rekan kerjanya menjadi tidak nyaman dalam bekerja, terutama dalam hal perasaan atau suasana hatinya.

Hubungan antara Beban Kerja dan Kepuasan Kerja Karyawan didukung dengan teori menurut Pradana dan Imam (2013: 116) menyimpulkan pada penelitian mereka bahwa kelebihan beban kerja berpengaruh secara signifikan negatif terhadap kepuasan kerja. Hubungan Konflik dengan Kepuasan kerja karyawan didukung dengan teori Cahyono33(2008). Konflik peran dapat menimbulkan situasi emosional individu misalnya terjadi ketegangan kerja, penurunan kepuasan kerja hingga berdampak pada organisasi dimana kualitas karyawan menurun dan tingkat keinginan berpindah kerja semakin meningkat.

\section{SIMPULAN}

Beban kerja secara keseluruhan, berdasarkan perhitungan pengkategorian persentase skor data diketahui bahwa beban kerja berada dikriteria tinggi. Hal ini menunjukan adanya beban kerja pada Konveksi Neptuns Screen Printing Sukabumi. Konflik Secara keseluruhan, berdasarkan perhitungan pengkategorian data yang didapatkan bahwa nilai konflik berada kriteria sedang. Hal ini diartikan bahwa konflik yang terjadi di dalam perusahaan masih bisa teratasi. Kepuasan secara keseluruhan, berdasarkan perhitungan pengkategorian data yang didapatkan bahwa nilai kepuasaan kerja karyawan berada kriteria sedang. Hal ini menunjukan bahwa kepuasaan kerja karyawan tergolong sedang, maka dapat diartikan kepuasaan kerja karyawan sudah 
terlihat baik dan cukup puas dengan pemberian kepuasaan yang diberikan perusahaan. Pengaruh beban kerja dan konflik terhadap kepuasan kerja karyawan memiliki pengaruh yang positif dan signifikan, hal tersebut dapat disimpulkan setelah pengujian hipotesis, dan hal-hal lain yang mempengaruhi kepuasan kerja karyawan yang dipengaruhi oleh faktor lain yang tidak diteliti dalam penelitian ini. Maka dari itu, apabila beban kerja dilakukan dengan baik dan konflik yang sesuai maka dapat meningkatkan kepuasan kerja karyawan

\section{DAFTAR PUSTAKA}

Fitriana, (2013). Faktor Konflik dalam pekerjaan. Dalam Studi Paparan Thesis ITB.

Handoko, (2000). Manajemen Sumber Daya Manusia. Yogyakarta: BPFE.

Hasibuan, (2001). Manajemen Sumber Daya Manusia : Pengertian Dasar, dan Masalah. Jakarta : PT.Toko Gunung Agung.

Mangkunegara, (2013). Manajemen Sumber Daya Manusia. Remaja Rosdakarya, Bandung.

Munandar. (2001). Psikologi Industri dan Organisasi. Depok. Penerbit Universitas Indonesia (UIPress).

Moekijat. (2004). Manajemen Tenaga Kerja dan Hubungan Kerja. Bandung penerbit CV. Pioner Jaya.

Soleman, (2011). Analisis Beban Kerja Ditinjau Dari Faktor Usia dan Pendekatan. Dalam Jurnal Arika. 